\title{
The Impact of COVID-19 Pandemic on Egyptian Women Psychological Empowerment and Work-Life Balance
}

\author{
Maha Ahmed Zaki Dajani ${ }^{1} \&$ Bassant Adel Mostafa ${ }^{1}$ \\ ${ }^{1}$ Business Department, Faculty of Business, Economics and Political Science, The British University in Egypt, Cairo, \\ Correspondence: Bassant, A., Mostafa, Business Department, Faculty of Business Administration, Economics and \\ Political Science, The British University in Egypt "BUE”, El Sherouk City, Suez Desert Road, Cairo 11837 - P.O. \\ Box 43, Egypt.
}

Received: January 26, 2021

Accepted: February 15, 2021 Online Published: February 18, 2021

doi:10.5430/jbar.v10n1p20

URL: https://doi.org/10.5430/jbar.v10n1p20

\begin{abstract}
The main objective of this study is to examine the impact of the COVID-19 Pandemic on Egyptian Women Psychological Empowerment and Work-Life Balance. The study was conducted on (107) Egyptian working women in different sectors and located in the Greater Cairo region. An online survey link was sent directly to these respondents to answer. They were selected using the non-probability judgmental sampling method; the only criterion for inclusion was that these respondents were working women operating in the Egyptian business context. Research hypotheses were tested using correlation and multiple regression analysis. After testing the effect of Egyptian working women's psychological empowerment dimensions on the perceived work-life balance, it was concluded that competence and self-determination dimensions were the two main psychological empowerment dimensions that positively affected the perceived work life balance. The other three dimensions: meaning, impact, and trust dimensions, had an insignificant effect on the perceived work-life balance. This research will help in designing a practical roadmap showing how to empower women psychologically while preserving their well-being and balancing their work-life duties and responsibilities. In addition to implementing work-life strategies and HR policies that will support working women in Egypt. Most of the studies have tackled the positive benefits of women empowerment and ignored its consequences on women's emotional and psychological well-being. Besides, few researches have been empirically administered on working women's psychological empowerment especially in Egypt.
\end{abstract}

Keywords: working women, psychological empowerment, work-life balance, Egypt

\section{Introduction}

Women's empowerment has been a big concern in several academic and social development organizations. In 2015, United Nations stated women empowerment as the 5th of the 17 Sustainable Development Goals to promote equity and educate women and girls (Miotto et al., 2019). In Egypt, as a country with an emerging economy, serious efforts have been made to address gender empowerment and enhance Egyptian women's socio-economic status. The explicit domestic goal has been women's financial empowerment (Kabeer, 2012). In the year 2017, Egyptian women's year had been announced (Nazier \& Ramadan, 2018). It reaffirms the state's legislative pledge to take the steps required to empower Egyptian women and ensure their equal inclusion in all decision-making positions (Klenke, 2017). However, less attention in Egypt's national gender policies and social welfare programs was given to working women's psychological empowerment and other emotional well-being life factors (Roudi-Fahimi \& Moghadam, 2006). In Egypt, different economic, social, and legal empowerment projects have struggled to produce anticipated outcomes, most undoubtedly attributable to a failure to consider the psychological makeup of working women empowered. Human beings are psychological entities, and in formulating policies that explicitly or implicitly apply to them must be regarded. If this is not done, the result can be negative (Saleem et al., 2017). Wrong attitudes and behaviors may be seen without psychological empowerment. An effort to address this issue would entail discussion of this nature; and its impact on work-life balance practices. This contemplated a significant dilemma and a demanding research gap that needed to be addressed.

The spread of the COVID-19 Pandemic globally and in Egypt locally imposed national lockdown declaration around the mid of March 2020 (El Desouky, 2020). Consequently, this has amplified the importance of women's psychological empowerment and the need for work-life balance, particularly when considering their multifaceted 
unpaid caregiver roles across multiple spheres: within their homes, local communities, and professional careers (El Desouky, 2020). COVID-19 crisis forced more unpaid work onto women and girls; and increased gender-based violence based on continued confinement with their abuser (Bradbury-Jones \& Isham, 2020). Besides, there was an apparent manifestation of female exclusion from leadership and senior managerial roles (Leal Filho et al., 2020). This resulted in a scenario where Egyptian working women faced tremendous pressure to develop a career as robust as their male counterparts while sustaining active engagement in personal life. Several researchers (Joseph \& Sebastian, 2017; Morello et al., 2019) stated that demographics include education, position, income, age, marital status, dependents, family nature and size, type of job, type of employed sector have a significant impact on work-life balance.

This study is focused on achieving the following objectives:

1) Examine working women's psychological empowerment within the Egyptian business context.

2) Explore the impact of Egyptian working women's psychological empowerment on work-life balance during the COVID-19 pandemic.

3) Predict future work scenarios for Egyptian working women post recovery from COVID-19 pandemic.

\section{Literature Review}

\subsection{Psychological Empowerment (PE)}

In the behavioral and social sciences, the empowerment construct is commonly used. Currently, the empowerment concept has often been considered as psychological empowerment. Psychological empowerment has been viewed as an opportunity for organizational actions (Gautam \& Ghimire, 2017). Empowerment has two things: "empowerment" as "behavior of a supervisor" who empowers his/her subordinates, and the other is the "psychological state of a subordinate "resulting from his/her supervisor's empowering" as suggested by Lee and Koh (2001). PE has intangible emotions with a range of perceived feelings (Avan et al., 2016). It also requires workers' perspectives to be committed and efficient throughout their daily lives and refers to different meanings for different people (Quinn \& Spreitzer, 1997). Previous researchers have found positive relationships between gender empowerment and positive behaviors towards the workplace, for instance, cooperative manners, job involvement, job satisfaction, and higher-quality performance (Eylon \& Bamberger, 2000; Spreitzer, 1995).

Ambad and Bahron (2012) stated that many organizations in developed countries, particularly public sector organizations, had been unable or unwilling to adopt PE. Their fear of losing influence over workers and the issues that could emerge from the wrong decisions by employees has been due to the hierarchical management strategy in addition to their embedded gender bias and rigid social norms that directly or indirectly limit women empowerment and cause copious adverse organizational outcomes, such as employees' dissatisfaction, poor performance and high turnover rates (Ibrahim et al., 2014). According to Spreitzer (1995), empowerment construct, measurement, and validation are a continuous variable; people can be viewed as more or less empowered, rather than empowered or not empowered. PE is a multidimensional term composed of four cognitive aspects that enable organizations to determine their empowerment. It manifests its competence, meaning, impact, and self-determination (autonomy) in four dimensions (Spreitzer, 1995). These four dimensions are expected to contribute to a holistic, relational empowerment system (Najafi et al., 2011; Spreitzer, 1995). In other terms, the loss of a single dimension declines the total degree of felt empowerment. Thus, the four dimensions describe the psychological empowerment of "almost full or adequate cognition" (Quinn \& Spreitzer, 1997). A fifth dimension called "trust" was then added to the previous four dimensions (Safari et al., 2020; Spreitzer \& Mishra, 1999), which can be best explained as follows:

Meaning accepts the working principles and goals of workers. That ensures that the demands of one's job obligations and one's interests, regulations, standards, and attitudes are compatible (Mohsen, 2014). This often represents a sense of mission or personal association with work and the extent to which an individual finds his / her actions contribute to the work of his / her company. Empowered individuals stated that they focus on their jobs and consider what they do (Stewart et al., 2010). Competence reflects individuals' beliefs that they have the necessary skills and abilities to perform their work well. In other words, the employees believe that they are capable and skilled enough to do the assigned duty and promote his/her performance (Kraimer et al., 1999). Competence is analogous to one's work role efficacy, agency beliefs, personal mastery, or effort performance expectancy (Bandura, 1989). It also combines the management and HR belief that said employees could use the organization's resources to perform their responsibilities. Thus, competence and self-efficacy enable working women to engage in the organization's dual roles and their families and project expectations for themselves into the future.

Self-determination (autonomy) is the individual's independence and perceived freedom in carrying out the work 
roles and the authority granted to him/her to make decisions regarding work systems, techniques, and processes (Liden et al., 2000). Also, self-determination is an individual's sense of having the choice in regulating actions, initiating processes, and making decisions (Vallerand, 2000). Thus, self-determination enables working women to make personal and career choices. Impact is the person's trust in his/her self-efficacy and his/her ability to produce high-quality job outcomes and to have an adequate degree of influence in one's family environment (Laschinger et al., 2001). It also reflects the degree to which an employee leads authentically and can influence strategic, administrative, or operative outcomes at work (Zhu et al., 2004). Impact for women means providing women with genuine opportunities to have not only their voice heard but giving them real power to control and exert influence overwork, life processes, and results (Zhu et al., 2004). Trust develops and evolves in an environment of empowerment; it needs unity and maturity. Unlike software, empowerment must be created, women cannot be empowered; however, we should build an atmosphere for them to be empowered (Gholipour et al., 2010). Individuals are able to sense the trust; they are assured that the strength and authority of the holders will not damage or injure them; in other words, they will be handled in a better way. They also believe like they are shielded from damage by their control (Ergeneli et al., 2007). The key aspects for motivating empowerment activities in women's life or job were stated above. Working women also need the empowered to educate, learn and trust to decide the direction they want to take and confront the organizational frameworks that hinder them (Gholipour et al., 2010).

\subsection{Work-Life Balance (WLB)}

Work-life balance is defined as a satisfactory level of involvement or 'fit' between the multiple roles in a person's life (Clarke et al., 2004). On the other hand, work-life imbalance occurs when the pressures from one role are overwhelming and causes difficulty to comply with the role's demands and requirements (Greenhaus \& Beutell, 1985). The philosophy of work-life balance is focused on the premise that work life and personal life support one another to accomplish one another (Johari et al., 2018). Philosophy of work-life balance stated that if working women don't allow to be looked after their families, they are depressed, dishonest, and angry. They discern close limits between job, family and don't want to cross over one another (Nelson \& Burke, 2002). Individuals share different interests and lifestyles (Burke 2002) because we also found that both men and women enjoy jobs in organizations that facilitate the work-life balance. Companies that effectively adopt the idea of work-life balance are favored by future workers and have the prestige of running.

That is why managing work and family responsibilities can be tough and challenging for working women; Egyptian working women are no exception. Especially during the COVID-19 pandemic, this burden just got multiplied (Alon et al., 2020). Egyptian working women tolerated a disproportionate burden of the care economy, such as taking care of children, the elderly, and other household duties, in addition to increased respect for infected family members, who are treated at home, as the hospitals were overworked. Hayman (2005) examined the items verified by three dimensions of the working life balance scale. The psychometric evaluation was used as a tool for measuring the work-life balance equilibrium. They are operationalized in the context of work interference with personal life (WIPL), personal life interference with work (PLIW), and work/personal life enhancement (WPLE). Those three things are composed of 15 questions used in their report. The three-factor approach provided appropriate reliability forecasts and factor loading patterns for the work-life balance scale. The outcome was 15 items work-life balance scale (Hayman, 2005; Najafi et al., 2011). According to Sundaresan (2014), there can be many reasons contributing to working women work-life imbalance, for example, the burden with excessive work in both their personal and workspaces; interference of work with family life; attempts to fulfil other's expectations, work longer work hours that leaves no time for one's self. Thus, in drawing future predictions for work scenarios, Egyptian working women seek a work-life balance portraying reconciliation between personal and professional life commitments and responsibilities.

\subsection{Working Women Empowerment and Work-Life Balance in Egypt amid COVID-19 Pandemic}

Egypt is considered an overpopulated country, and women constitute nearly half or more of its total population. Focus (2020) stated that increasing numbers of Egyptian working women enter the workplace and join the labor force; while continuing to do the majority of unpaid family roles. Consequently, it is becoming more difficult to reconcile family and work responsibilities for these female employees, particularly with the lack of national female strategies supporting working women's psychological well-being (El-Kot et al., 2019). On one end, it is said that Women's Empowerment is necessary for the upliftment of society, and equally, on the other end, the Work-Life Balance becomes a limitation for working women to uplift themselves and show their core competencies (Rahaman \& Tul-Jannat, 2015). In their desire to reconcile work and home-family duties, many Egyptian women today carry many hats. Family concerns can conflict with employment to a considerable degree, and family concerns may often 
be shown. Moreover, the COVID-19 epidemic is detrimental to health, social, and economic well-being worldwide and impacts Egyptian women and women at the center. Women drive the health response firstly. Also the new coronavirus outbreak, many organizations are implementing voluntary or perhaps mandatory work-from-home policies, and it is a challenge for women who are managing both personal as well as professional life because of pandemic doing all day to day activities at home, managing office work, taking care of kids, older people, etc., really hectic task for women to do all these things (Swarnalatha \& Lailitha, 2020)

According to ILO report 2020, women make up almost $70 \%$ of the population, leading women to higher infection risk. Women bear a significant part of their life at home, gender gaps at the workplace. A woman also faces increased risks of loss of employment and economic downturn and growing threats of violence, exploitation (Power, 2020). Thus, both Women's Empowerment and Work-Life Balance became the most recent topics that have attracted most researchers (Pandey, 2020). However, PB and WLB research was considered outdated, inappropriate, conceptually incorrect, and criticized for analytical conceptualization. The current findings are general and without an objective foundation. Given the growing attention provided to study in the region, there is still empirically insufficient data on the relation between PE and WLB. In comparison, the bulk of current findings are descriptive in general and ignore methodological foundations. In addition, there has been significant independent study work in both PE and WLB fields, although exploration of its connection has been primarily limited to Western societies. Therefore, this study aims to fill this research gap, specifically in Egypt.

\subsection{Conceptual Framework and Research hypotheses}

Based on the above theoretical review, the following figure represents the proposed model of this study.

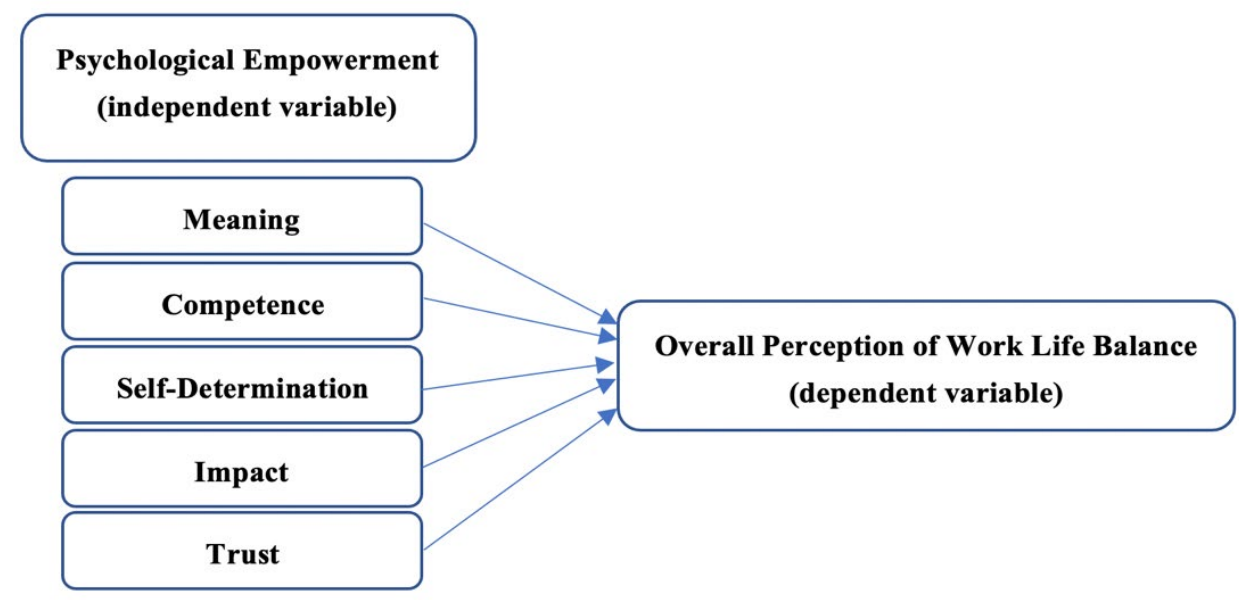

Figure 1. Conceptual Research Model

Hypothesis 1 (H1): The Psychological Empowerment (PE) constructs have a significant positive effect on the Egyptian working women's work-life balance (WLB) during the COVID-19 Pandemic.

H1.a. There is a significant positive effect of PE-meaning on WLB.

H1.b. There is a significant positive effect of PE-competence on WLB.

H1.c. There is a significant positive effect of PE- self-determination on WLB.

H1.d. There is a significant positive effect of PE-impact on WLB.

H1.e. There is a significant positive effect of PE-trust on WLB.

\section{Methodology}

\subsection{Description of Sample}

The study was conducted among 107 working women employed from different sectors (Education, Banking, Telecommunication, Fast-moving consumer goods, Automotive, Retail, Pharmaceutical, Real estate, Software development, Healthcare) located in the greater Cairo region; an online survey link (Note 1) was sent directly to the respondents to answer. They were selected using the non-probability judgmental sampling method; the only criterion 
for inclusion was that the respondents were Egyptian working women. All the respondents are working women, the majority were above 35 years old $(n=62,58 \%)$, meanwhile for the monthly salary; most of the respondents concentrated in the category of 20,000 LE to less than 30,000 LE $(n=35,33 \%)$, followed by less than 10,000 LE ( $n$ $=31,29 \%), 40 \%$ got there doctoral degree, and $(n=51,48 \%)$ of the respondents are married with children and $(n=$ $46,43 \%)$ are single while $(n=62,58 \%)$ of the respondents occupy a middle managerial or supervisory level and $(n=$ $68,64 \%$ ) with more than 8 years of working experience, the sample composed of employees working mainly in the Educational sector $(n=63,59 \%)$ while $41 \%$ distributed among other sectors, finally $(n=63,59 \%)$ of the respondents support their families financially.

\subsection{Measurements}

Data was collected using a structured questionnaire composed of three sections: the first part covers items related to the respondents' demographic information. Meanwhile, the remaining parts cover the research variables, namely the independent variables (women's psychological empowerment) and the dependent variable (women perception of work-life balance). On each question's responses were provided scores ranging from 1-5 (1-Strongly disagree, 2disagree, 3-Neutral, 4- Agree, 5-Strongly agree); the questionnaire ends up by asking respondents about how they perceive their future work scenario post-COVID-19 pandemic recovery.

The psychological empowerment variable is measured using the four dimensions developed by Spreitzer's (1995) psychological empowerment scale with a reliability of 0.72 , modified by Gholipour et al., (2010) who added a fifth dimension (trust dimension) to come up with an overall measure for psychological empowerment with a reliability of 0.85. A sample item included is "[...] I have significant freedom in determining how I do my job."

Women perception of a work-life balance was adapted from the study of (Hayman, 2005) who developed 15 items scale including three dimensions; work interference with personal life (WIBL), personal life interference with work (PLIW) and work personal life enhancement (WPLE) and modified by (Helmle et al., 2014) with a reliability of 0.79 but one item was dropped owing to the least factor loading in the three dimensions; A sample item included is "[...] My personal life suffers a lot because of work."

\subsection{Data Analysis}

To measure the independent variable's effect on the dependent variables, the Pearson correlation coefficient was first used to represent the strength and direction of the relationship between the dependent and independent variables. A regression analysis was conducted to examine the extent to which the independent variable influences the dependent variable to test research hypotheses after ensuring the reliability and validity of the measures using SPSS software version 16.

\section{Results}

The psychological empowerment was measured using 15 items; the Cronbach's alpha coefficient was.940 for the total scale. A principal components analysis with varimax rotation was applied to the 15 items from the psychological empowerment scale to explore the factor structure in the data set. A Kaiser-Meyer-Olkin (KMO) measure of sampling adequacy statistic was conducted with a value of.857. The high value indicates that the pattern of correlations among items and Bartlett's test of sphericity was statistically significant, indicating the suitability of the data for factor analysis. Women's perception of the Work-Life Balance scale was measured using 14 items. The Cronbach's alpha coefficient was.814 for the total scale, and a principal components analysis with varimax rotation was applied to the 14 items from the work-life balance scale to explore the factor structure in the data set. The KMO measure of sampling adequacy was.778; the high value indicates that the pattern of correlations among items and Bartlett's test of sphericity was statistically significant, meaning the data's suitability for factor analysis. 
Table 1. Means and Standard Deviation

\begin{tabular}{llc}
\hline Research Variables & Mean & Standard Deviation \\
\hline Psychological Empowerment & 3.65 & .788 \\
Meaning & 3.99 & 1.005 \\
Competence & 4.01 & .927 \\
Self-determination & 3.56 & 1.075 \\
Impact & 3.37 & 1.011 \\
Trust & 3.34 & .988 \\
Work-Life Balance & 3.15 & .606 \\
\hline
\end{tabular}

Table 1 showed that the overall psychological empowerment was perceived to be high $(\operatorname{mean}=3.65)$. The five dimensions of PE are all perceived positively by the respondents, with mean scores above three. The competence dimension has the highest mean score (4.01) across the five dimensions, followed by meaning and self-determination dimensions with a mean score of (3.99 and 3.56) respectively. As for the perceived work-life balance, the respondents show a relatively moderate score with a mean of 3.15 .

Table 2. Correlation test between Psychological Empowerment and Work-life Balance

\begin{tabular}{lcc}
\hline Research Variables & $\begin{array}{c}\text { Pearson } \\
\text { Correlation Coefficient }\end{array}$ & Significance (two-tailed) ${ }^{*}$ \\
\hline Psychological Empowerment & .204 & .035 \\
Meaning & .137 & .158 \\
Competence & .248 & .010 \\
Self-determination & .330 & .001 \\
Impact & .038 & .698 \\
Trust & .169 & .082 \\
\hline
\end{tabular}

*Correlation is significant at $\mathrm{p} \leq 0.05$ (two-tailed).

Table 2 showed that after conducting a correlation test, it was first revealed that there is a significant positive relationship between psychological empowerment and perceived work-life balance with a correlation coefficient value.204, at $\mathrm{p} \leq 0.05$, which means that respondents who are more empowered enjoy more work-life balance; moreover, table 3 shows that among the three dimensions of PE, competence dimension has a significant positive correlation with work-life balance with a correlation coefficient value of.248 at $p \leq 0.05$ in addition to self-determination dimension which has a significant positive correlation with work-life balance with a correlation coefficient value of.330 at $\mathrm{p} \leq 0.05$. At the same time, the other three dimensions are insignificantly correlated with work-life balance. This means that competence and self-determination dimensions are more important than the other PE dimensions in relation to employees' perception of work-life balance. 
Table 3. Multiple Linear Regression Model for the effect of PE and Work-life Balance

\begin{tabular}{llllllll}
\hline \multirow{2}{*}{ Model } & \multicolumn{2}{l}{$\begin{array}{l}\text { Unstandardized } \\
\text { Coefficients }\end{array}$} & \multicolumn{2}{l}{ Standardized Coefficients } & \multicolumn{2}{c}{$\mathrm{T}$} & \multicolumn{2}{c}{$\mathrm{F}$} \\
\cline { 2 - 7 } & $\mathrm{B}$ & Std. Error & Beta & Value & Sig. & Value & Sign. \\
\hline (Constant) & .204 & .415 & & .872 & .385 & & \\
Meaning & .137 & .128 & .035 & .253 & .801 & & \\
Competence & .248 & .130 & .227 & 1.744 & .008 & & \\
Determination & .330 & .107 & .347 & 2.776 & .007 & 3.341 & $008^{\mathrm{e}}$ \\
Impact & .038 & .118 & .078 & .603 & .548 & & \\
Trust & .169 & .114 & .072 & .592 & .555 & & \\
\hline Depent & & & & & &
\end{tabular}

Dependent Variable: Work-life balance.

Following the correlation analysis, a multiple regression analysis was conducted which is a multivariate technique that is used when more than one independent variable used to explain the variance in the dependent variable (Malhotra et. al., 2017), the regression coefficient indicates the relative importance of each psychological empowerment dimension in the prediction of work-life balance. After analyzing the influence of the five psychological empowerment dimensions on the perceived work-life balance, the results presented in table 3 showed that the self-determination dimension $(\beta=.297, \mathrm{t}(2.776), \mathrm{p} \leq .05)$ has the strongest significant effect on the perceived work-life balance, followed by competence dimension $(\beta=.226, \mathrm{t}(1.744), \mathrm{p} \leq .05)$. In contrast, impact, trust, and meaning dimensions are insignificant predictors. As for the $\mathrm{R}^{2}$, which is equal to.142, it means that $14 \%$ of the perceived work-life balance variance accounted for the competence and self-determination dimensions together.

Table 4. Future Work Scenario Post-COVID-19 Pandemic Recovery

\begin{tabular}{lll}
\hline Alternative & Frequency & Percentage \\
\hline Prefer part-time over a full-time job & 14 & $13 \%$ \\
Prefer to work online for the rest of my career & 17 & $16 \%$ \\
Go for resignation from my current employer & 2 & $2 \%$ \\
Reluctant to go back to my office after working from home & 9 & $8 \%$ \\
Have a right balance between the time I spend at work and the & 40 & $37 \%$ \\
time available for non-work activities & \multicolumn{2}{|}{$2 \%$} \\
Decide to Shift Career & 2 & $6 \%$ \\
Better psychological empowerment & 6 & $1 \%$ \\
Miss out on promotion & 1 & $2 \%$ \\
Negative impact on my compensation package & 2 & $10 \%$ \\
less stress at work & 11 & $3 \%$ \\
Other & 3 &
\end{tabular}

Finally, the respondents were asked about their projections on the future work scenario post-COVID-19 pandemic recovery, and they were asked to select the most alternative that best describes their choice, as listed in table 4 . It demonstrates that $37 \%$ of working women in Egypt craved to achieve WLB post-COVID-19 recovery, followed by $16 \%$ who started to prefer working online for the remaining period of their career; this confirms the regression results and correlation analysis. Moreover, this affirms with the demographical characteristics of this research sample. In which, $58 \%$ of the research sample ranged from (35- 45) years old and $61 \%$ attained a high educational degree (master and doctoral degree), while 58\% are positioned as middle-level management. In other words, they possess competency and self-determination, which compose the highest influential dimensions of psychological empowerment evidenced in this research paper. 


\section{Discussion and Conclusion}

This study's main objective is to examine the effect of women's psychological empowerment dimensions on the perceived work-life balance during COVID-19. The main hypothesis showed that at a $95 \%$ confidence level, there was a significant positive relationship between women's psychological empowerment and the perceived work-life balance as a whole, as presented in table (2). During the COVID -19 pandemic, with the increase of women's psychological empowerment, work-life balance also increases. After testing the effect of women psychological empowerment dimensions on the perceived work-life balance, it was proposed in H1a that there is a significant positive effect of PE-meaning on WLB; following the results in table (3), the meaning dimension of PE has an insignificant impact on the perceived WLB with the $\beta$ coefficient of.032; therefore, H1a is rejected.

In $\mathrm{H} 1 \mathrm{~b}$, it was claimed that there is a significant positive effect of PE-competence on the perceived WLB. In line with the findings in table (3), it is observed that the competence dimension of PE has a significant positive effect on the perceived WLB with the $\beta$ coefficient of. 226. This is consistent with (Ambad \& Bahron, 2012), who noted that feeling competent in dealing with one's job requirements is positively correlated with WLB. This result is also in line with (Spreitzer 1995) and (Goretzki 2016), who have attested that employees will not feel empowered unless they have confidence in their capabilities. In a similar vein, Kamel (2020) asserted that working women who feel higher competency would experience a better WLB as they possess the needed experience and ability to perform their tasks and enjoy time for themselves. On the other hand (Jannat et al., 2019) claimed that WLB might become a significant challenge for empowered women, inhibiting them from manifesting their work competencies and creating sufficient opportunity to actualize their talents, abilities, and experiences in the best feasible manner. Therefore, H1b is accepted.

In H1c, it was claimed that there is a significant positive effect of PE- self-determination on WLB. In line with the findings in table (3), it is observed that the self-determination dimension of PE has a significant positive effect on the perceived WLB with the $\beta$ coefficient of.297. Thus, by increasing the sense of self-determination, the WLB increases; hence, it can be assumed that when women are autonomous and in control over the methods/resources used to accomplish a task, the amount of effort, time that must be exerted to get the work done, they will have a sense of ownership for the work and this increases their ability to balance between work and life-related activities. These results complement (Chiang \& Jang, 2008) and (Kraimer et al., 1999), who concluded that self-determination was the strongest PE dimension in terms of its influence on Organizational Commitment and Job Security. Therefore, $\mathrm{H} 1 \mathrm{c}$ is accepted.

In H1d, there is a significant positive effect of PE-impact on WLB. It was observed from table (3) that the impact dimension of PE has an insignificant effect on the perceived WLB with the $\beta$ coefficient of. 071.Therefore, H1d is rejected. Finally, H1e claimed that there is a significant positive effect of PE-trust on WLB. According to the results of table (3), the trust dimension of PE has an insignificant impact on the perceived WLB with the $\beta$ coefficient of.067. Therefore, H1e is rejected. Accordingly, Hypothesis 1, which stated that the Psychological Empowerment (PE) constructs significantly affect Egyptian working women's work-life balance (WLB) during the COVID-19 Pandemic, is partially accepted.

\section{Managerial Implications and Recommendations}

This research can be used as a pillar for organizations who want to understand better the connection between empowering women employees and sustaining their perceived WLB. This can help practitioners develop the appropriate psychological empowerment practices for their women employees based on the most effective dimensions shown to increase WLB and decide which empowerment practices they should prioritize to improve if they want to achieve a higher degree of WLB among their women employees. Given that the competence and self-determination dimensions have a positive and significant effect on perceived work-life balance. It is recommended that managers place employees on work teams to develop their internal talents and boost their self-confidence in their inherent capabilities. In such cases, when employees are given discrete responsibilities, they may feel better toward themselves and their jobs, or as proposed by (El-Kot et al., 2019), increasing levels of employee self-efficacy through training and more effective use of their work experiences will increase personal empowerment and improve work outcomes, and as a result, this increases their ability in balancing between their work and life. Also, an individual with a high sense of self-determination feels autonomy and freedom to engage and develop new ideas of efficiently and effectively carrying out organizational processes (Safari et al., 2020). Therefore, it is suggested that managers provide employees enough independence and control over operations in terms of flexibility in effort and times exerted. Finally, empowerment practices have the potential to yield positive outcomes for both employees and workplaces through increasing employee participation in decision-making, delegating 
authority and control to these employees, creating more challenging work roles through job redesign, leaders sharing more information, and leaders providing more coaching and mentoring to their staff as suggested by (Lee et al., 2018).

\section{Limitations and Future Research}

This current study involves several limitations. Despite that, two out of five psychological empowerment dimensions have a significant effect on WLB but with a small magnitude, and this could be attributed to the small sample size where only 107 respondents were involved in the study, which is quite consequential for the ability to derive insights into the understudied research, which limit the generalizability of the current results. Future studies may consider using a longitudinal research design, which should include larger and more representative samples of managers and professionals; conducting a comparative analysis for employees from other countries/cultures is also recommendable. At the same time, participants were selected from various sectors, and each industry is affected by COVID - 19 pandemics differently, which calls for a future study comparing the effect of COVID-19 on these sectors differently as the nature and characteristics of each industry differ significantly. Besides, including more work-related attitudinal and behavioral outcomes of psychological empowerment such as work engagement, job performance evidence, or negative consequences such as absenteeism, burnout would strengthen conclusions about the potential benefits and drawbacks of women empowerment in organizations. It is also suggested for future studies to measure the effect of the five dimensions describing psychological empowerment on the three dimensions of work-life balance separately. Other moderating variables that might have an impact on the relationship between psychological empowerment and WLB could be included, such as employees' satisfaction, demographics, and leadership styles. It is also suggested to employ different statistical techniques like ordered probit or logit to enrich the research results in the future research. In addition to studying the effect of socio-economic factors such as gender, age, marital status on the relationship between the research variables.

\section{Conflict of Interest}

The authors declare that they don't have conflict of interest.

\section{References}

Alon, T. M., Doepke, M., Olmstead-Rumsey, J., \& Tertilt, M. (2020). The impact of COVID-19 on gender equality. National Bureau of Economic Research. https://doi.org/10.3386/w26947

Ambad, S. N. A., \& Bahron, A. (2012). Psychological empowerment: The influence on organizational commitment among employees in the construction sector. Journal of Global Business Management, 8(2), 73. http://www.jgbm.org/page/9\%20Arsiah\%20Bahron.pdf

Avan, A., Zorlu, Ö., \& Baytok, A. (2016). The effect of psychological empowerment on organizational silence in hotels. Journal of Business Research-Turk, 8(4), 277. https://doi.org/10.20491/isarder.2016.219

Bandura, A. (1989). Regulation of cognitive processes through perceived self-efficacy. Developmental Psychology, 25(5), 729. https://doi.org/10.1037/0012-1649.25.5.729

Bradbury-Jones, C., \& Isham, L. (2020). The pandemic paradox: The consequences of COVID-19 on domestic violence. Journal of Clinical Nursing. https://doi.org/10.1111/jocn.15296

Burke, R. J. (2002). Organizational values, job experiences and satisfactions among managerial and professional women and men: advantage men? Women in Management Review. https://doi.org/10.1108/09649420210433184

Chiang, C.-F., \& Jang, S. (2008). antecedents anThed consequences of psychological empowerment: the case of Taiwan's hotel companies. Journal of Hospitality \& Tourism Research, 32(1), 40-61. https://doi.org/10.1177/1096348007309568

Clarke, M. C., Koch, L. C., \& Hill, E. J. (2004). The work-family interface: differentiating balance and fit. Family and Consumer Sciences Research Journal, 33(2), 121-140. https://doi.org/10.1177/1077727X04269610

El-Kot, G., Burke, R. J., \& Fiksenbaum, L. M. (2019). women supervisory empowerment behaviEgyptianors on well-being outcomes. Gender in Management, 34(5), 350-365. https://doi.org/10.1108/GM-12-2018-0165

El Desouky, E. D. (2020). Prediction of the Epidemic Peak of Covid19 in Egypt, 2020. MedRxiv. https://doi.org/10.1101/2020.04.30.20086751

Engineering, T., \& Pandey, M. (2020). Post COVID-19 World- A Paradigm Shift at Workplace. Test Engineering and Management, 83, 27675- 27687. 
Ergeneli, A., Arı, G. S., \& Metin, S. (2007). Psychological empowerment and its relationship to trust in immediate managers. Journal of Business Research, 60(1), 41-49. https://doi.org/10.1016/j.jbusres.2006.09.012

Eylon, D., \& Bamberger, P. (2000). Empowerment cognitions and empowerment acts: Recognizing the importance of gender. Group \& Organization Management, 25(4), 354-372. https://doi.org/10.1177/1059601100254003

Focus, I. N. (2020). April 2020 women's economic empowerment and COVID-19: A snapshot of UN women, 1-8. Retrieved from https://egypt.unwomen.org/en/digital-library/publications/2020/04/womens-economicempowerment-and-covid19-a-snapshot-of-un-women-response

Gautam, D. K., \& Ghimire, S. B. (2017). Psychological empowerment of employees for competitive advantages. International Journal of Law and Management. https://doi.org/10.1108/JJLMA-03-2016-0035

Gholipour, A., Rahimian, A., Mirzamani, A., \& Zehtabi, M. (2010). IMPACT model of women's empowerment. International Business Research, 3(1), 57. https://doi.org/10.5539/ibr.v3n1p57

Goretzki, M. (2016). Determinants of perceived job security. University of Twente. Retrieved from https://essay.utwente.n1/70997/1/Goretzki_MA_BMS.pdf

Greenhaus, J. H., \& Beutell, N. J. (1985). Sources of conflict between work and family roles. Academy of Management Review, 10(1), 76-88. https://doi.org/10.2307/258214

Hayman, J. (2005). Psychometric assessment of an instrument designed to measure work life balance. Research and Practice in Human Resource Management, 13(1), 85-91.

Helmle, J., R. Botero, I. C., \& R. Seibold, D.R. (2014). Factors that influence perceptions of work-life balance in owners of copreneurial firms. Journal of Family Business Management, 4(2), 110-132. https://doi.org/10.1108/JFBM-06-2014-0013

Ibrahim, M. M., El-Magd, M. H. A., \& Sayed, H. Y. (2014). Nurse's psychological empowerment and perceived autonomy in university and teaching hospitals at Menofia Governorate/Egypt. Journal of Nursing Education and Practice, 4(9), 59. https://doi.org/10.5430/jnep.v4n9p59

Jannat, S. M. T., Rahman, Z. U., \& Kumar, R. (2019). Critical investigation on how business ethics can have a positive impact on employee retention in the Ready-Made Garments (RMG) sector of Bangladesh?. Journal of Research in Business and Management, 7(4), 1-16

Johari, J., Yean Tan, F., \& Tjik Zulkarnain, Z. I. (2018). Autonomy, workload, work-life balance and job performance among teachers. International Journal of Educational Management, 32(1), 107-120. https://doi.org/10.1108/IJEM-10-2016-0226

Joseph, J., \& Sebastian, D. J. (2017). Do the Demographics have the potential to influence Work-Life Conflict? International Journal of Research Culture Society, 1(6), 166-171.

Kabeer, N. (2012). Women's economic empowerment and inclusive growth: labour markets and enterprise development. International Development Research Centre, 44(10), 1-70.

Kamel, N. A. (2020). The effect of psychological empowerment on employees' commitment in travel agencies: The moderating role of perceived job security. African Journal of Hospitality, Tourism and Leisure, 9(1), 1-18.

Klenke, K. (2017). Women in leadership: Contextual dynamics and boundaries. Emerald Group Publishing. https://doi.org/10.1108/9781787430631

Kraimer, M. L., Seibert, S. E., \& Liden, R. C. (1999). Psychological empowerment as a multidimensional construct: A test of construct validity. Educational and Psychological Measurement, 59(1), 127-142. https://doi.org/10.1177/00131649921969785

Laschinger, H. K. S., Finegan, J., Shamian, J., \& Wilk, P. (2001). Impact of structural and psychological empowerment on job strain in nursing work settings: expanding Kanter's model. JONA: The Journal of Nursing Administration, 31(5), 260-272. https://doi.org/10.1097/00005110-200105000-00006

Leal Filho, W., Brandli, L. L., Lange Salvia, A., Rayman-Bacchus, L., \& Platje, J. (2020). COVID-19 and the UN sustainable development goals: threat to solidarity or an opportunity? Sustainability, 12(13), 5343. https://doi.org/10.3390/su12135343

Lee, A. J. R., Willis, S., \& Tian, A. (2018). When empowering employees works, and when it doesn't. Harvard Business Review. Retrieved from https://hbr.org/2018/03/when-empowering-employees-works-and-when-it-doesnt 
Lee, M., \&Koh, J. (2001). Is empowerment really a new concept? International Journal of Human Resource Management, 12(4), 684-695. https://doi.org/10.1080/713769649

Liden, R. C., Wayne, S. J., \& Sparrowe, R. T. (2000). An examination of the mediating role of psychological empowerment on the relations between the job, interpersonal relationships, and work outcomes. Journal of Applied Psychology, 85(3), 407. https://doi.org/10.1037/0021-9010.85.3.407

Malhotra, N. K., Nunan, D., \& Birks, D. F. (2017). Marketing research: An applied approach. Pearson Education Limited.

Miotto, G., Polo López, M., \& Rom Rodríguez, J. (2019). Gender equality and UN sustainable development goals: Priorities and correlations in the top business schools' communication and legitimation strategies. Sustainability, 11(2), 302. https://doi.org/10.3390/su11020302

Mohsen, M. (2014). Psychological empowerment and job satisfaction in the hotel industry: a study on Egyptian employees in KSA hotels. 32nd Euro CHRIE Conference "Hospitality and Tourism Futures", Dubai, 6-9.

Morello, S. L., Colopy, S. A., Bruckner, K., \& Buhr, K. A. (2019). Demographics, measures of professional achievement, and gender differences for diplomates of the American College of Veterinary Surgeons in 2015. Journal of the American Veterinary Medical Association, 255(11), 1270-1282. https://doi.org/10.2460/javma.255.11.1270

Najafi, S., Noruzy, A., Azar, H. K., \& Nazari-shirkouhi, S. (2011). Investigating the relationship between organizational justice, psychological empowerment, job satisfaction, organizational commitment and organizational citizenship behavior: An empirical model. African Journal of Business Management, 5(13), 5241-5248. https://doi.org/10.5897/AJBM10.1505

Nazier, H., \& Ramadan, R. (2018). What empowers Egyptian women: resources versus social constrains? Review of Economics and Political Science, 3(3/4), 153-175. https://doi.org/10.1108/reps-10-2018-015

Nelson, D. L., \& Burke, R. J. (2002). Gender, work stress, and health. American Psychological Association. https://doi.org/10.1037/10467-000

Power, K. (2020). The COVID-19 pandemic has increased the care burden of women and families. Sustainability: Science, Practice and Policy, 16(1), 67-73. https://doi.org/10.1080/15487733.2020.1776561

Quinn, R. E., \& Spreitzer, G. M. (1997). The road to empowerment: Seven questions every leader should consider. Organizational Dynamics, 26(2), 37-49. https://doi.org/10.1016/S0090-2616(97)90004-8

Rahaman, A., \& Tul-Jannat, K. (2015). Reconciliation of Professional and Personal Life: An Empirical Work Life Balance Study on Context of Women Empowerment. International Journal of Economics, Commerce and Management, 3(9), 207-219. https://ssrn.com/abstract=2671498

Roudi-Fahimi, F., \& Moghadam, V. M. (2006). Empowering women, developing society: Female education in the Middle East and North Africa. Al-Raida Journal, 4-11. https://doi.org/10.32380/alrj.v0i0.221

Safari, A., Adelpanah, A., Soleimani, R., Heidari Aqagoli, P., Eidizadeh, R., \& Salehzadeh, R. (2020). The psychological empowerment on job bffect of psurnout and competitive advantage: The mediating role of organizational commitment and creativity. Management Research, 18(1), 47-71. https://doi.org/10.1108/MRJIAM-06-2019-0935

Saleem, S., Rafiq, A., \& Yusaf, S. (2017). Investigating the glass ceiling phenomenon: An empirical study of glass ceiling's effects on selection-promotion and female effectiveness. South Asian Journal of Business Studies, 6(3), 297-313. https://doi.org/10.1108/SAJBS-04-2016-0028

Spreitzer, G. M. (1995). Psychological Empowerment in the Workplace: Dimensions, Measurement, and Validation. Academy of Management Journal, 38(5), 1442-1465. https://doi.org/10.5465/256865

Spreitzer, G. M., \& Mishra, A. K. (1999). Giving up control without losing control: Trust and its substitutes' effects on managers' involving employees in decision making. Group \& Organization Management, 24(2), 155-187. https://doi.org/10.1177/1059601199242003

Stewart, J. G., McNulty, R., Griffin, M. T. Q., \& Fitzpatrick, J. J. (2010). Psychological empowerment and structural empowerment among nurse practitioners. Journal of the American Academy of Nurse Practitioners, 22(1), 27-34. https://doi.org/10.1111/j.1745-7599.2009.00467.x

Sundaresan, S. (2014). Work-Life Balance - Implications for Working Women. OIDA International Journal of 
Sustainable

Development,

$7(7)$

93-102.

Rerieved

from http://www.ssrn.com/link/OIDA-Intl-Journal-Sustainable-Dev.html

Swarnalatha, V. \& Lailitha, P. (2020). Work-Life Balance in Pandemic: a Conceptual Study of Problems and challenges faced by working professionals. Mukt Shabd Journal, 9(5), 6173-6179. Rerieved from https:/www.researchgate.net/publication/342158681

Vallerand, R. J. (2000). Deci and Ryan's self-determination theory: A view from the hierarchical model of intrinsic and extrinsic motivation. Psychological Inquiry, 11(4), 312-318. Rerieved from https://www.jstor.org/stable/1449629

Zhu, W., May, D. R., \& Avolio, B. J. (2004). The impact of ethical leadership behavior on employee outcomes: The roles of psychological empowerment and authenticity. Journal of Leadership \& Organizational Studies, 11(1), 16-26. https://doi.org/10.1177/107179190401100104

\section{Notes}

Note 1. Survey Link: https://docs.google.com/forms/d/e/1FAIpQLSdQfcFGBqHkrnpnQCPm_ gePO3d0TkwAy67bSYzhA_HHsJLLyg/viewform

\section{Copyrights}

Copyright for this article is retained by the author(s), with first publication rights granted to the journal.

This is an open-access article distributed under the terms and conditions of the Creative Commons Attribution license (http://creativecommons.org/licenses/by/4.0/). 